Arch. Tierz., Dummerstorf 45 (2002) 4, 387-401

Research Institute for the Biology of Farm Animals Dummerstorf and University Rostock*, Germany

HARTMUT FRANZ, EVGENY ROITBERG, BERTHOLD LÖHRKE, GERD NÜRNBERG, GERHARD DIETL and RAGNAR KINZELBACH*

\title{
Visual discrimination learning of group-housed goats at an automated learning device
}

\begin{abstract}
Summary
A general purpose computer system for behavioral conditioning experiments, the 'Fields-Monitor', was developed and has been in use for several years. The set-up allows flexible stimulus presentations and rewards for different kinds of learning behavior in animals. It enables training and testing of animals even under group housing conditions which prevent the social isolation and possible distorting influences resulting from the experimenter or from the time of the day (the test animals visit the learning device whenever they want). Thus, it eliminates most of the stress factors known to decrease learning success. Using this device, 160 dwarf goats were trained for visual discrimination of four stimulus patterns (simple geometric figures, Roman letters) presented simultaneously. One of these patterns was rewarded with a small portion of water after each correct choice. A comparison of mean learning curves in the three consecutive tests showed that in the second and third test successful learning started earlier and reached a higher level $\left(70-80 \%\right.$ correct choices as early as the $5-6^{\text {th }}$ Test Day) than in Test 1 (about $60 \%$ correct choices at the $10^{\text {th }}$ Test Day). The coefficient of variation of average learning success for 10 days was 28.4, 18.7, $16.8 \%$ in Test 1 - 3 respectively, indicating great differences between the animals. All animals could use the learning equipment voluntarily over several weeks, without any social deprivation.
\end{abstract}

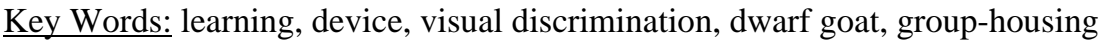

\section{Zusammenfassung}

Titel der Arbeit: Visuelles Lernen von in Gruppen gehaltenen Ziegen an einer automatischen Lernapparatur

Eine vielseitig einsetzbare, vollautomatische Lernapparatur, der "Feldermonitor", wurde entwickelt und seit einigen Jahren genutzt. Diese Lernapparatur ermöglicht einen flexiblen Einsatz der Stimuli und verschiedener Belohnungsformen für die Prüfung unterschiedlicher Arten des Lernverhaltens von Tieren. Sie ermöglicht das Training und die Prüfung von Tieren unter den Bedingungen einer Gruppenhaltung und vermeidet damit die soziale Isolation und mögliche störende Einflüsse durch den Versuchsansteller oder die Tageszeit ( die Testtiere können den Feldermonitor nutzen, wann immer sie es wollen). Damit werden die meisten Stressfaktoren ausgeschaltet, die den Lernerfolg beeinflussen können. Mit dieser Lernapparatur wurden 160 Zwergziegen in drei aufeinanderfolgenden Tests auf die visuelle Differenzierung von vier, gleichzeitig präsentierten Stimuli trainiert (einfache geometrische Figuren, lateinische Druckbuchstaben). Die Auswahl eines dieser Stimuli wurde mit einer kleinen Portion Trinkwasser belohnt. Ein Vergleich der mittleren Lernkurven aus den drei aufeinanderfolgenden Tests zeigte, dass im zweiten und dritten Test der Lernerfolg früher einsetzt und ein höheres Niveau erreicht (70-80\% Richtigwahl am 5.-6. Testtag), als im ersten Test (etwa 60 \% Richtigwahl am 10. Testtag). Der Variationskoeffizient für den durchschnittlichen Lernerfolg der ersten 10 Tage jedes Tests war 28,4, 18,7 bzw. 16,8 \% in Test 1-3 und weist damit auf große Differenzen im Lernerfolg zwischen den Tieren hin. Alle Tiere konnten die Lernapparatur freiwillig über mehrere Wochen nutzen, ohne dabei sozial depriviert zu werden.

Schlüsselwörter: Lernen, Apparatur, visuelle Diskriminierung, Zwergziege, Gruppenhaltung 


\section{Introduction}

Modern animal husbandry is increasingly characterised by automation in feed and water supply, care, and even in cow-milking. Electronic feeders are widely used with calves, cattle, pigs, and poultry, and in European dairy farms more than 600 different robotic milking systems are employed. Within this framework, cognitive abilities in farm animals are becoming increasingly important. Most of the systems that are on offer, integrate the interactions between animals and technology only on a low level, however. One of the reasons for this might be an incomplete knowledge of farm animal cognition.

The learning abilities of farm animals have only rarely been subject of research (FRANZ, 1999; FRANZ et al., 1999). Agricultural research activities traditionally concentrated on the yields of animals. For the experimental psychologist most farm animals did not seem suitable subjects. The "classical" learning devices like the Skinner-box, Morris-water-maze or labyrinths cannot easily be adapted to larger animals. According to review articles (KILGOUR et al., 1991; ARAVE, 1996) and our own results a plethora of approximately 90,000 publications on learning in laboratory and zoo animals contrasts sharply with only 300 papers dealing with farm animals in the last fifty years. Hence, there are big deficits in our knowledge of learning and cognition in these species (NICOL, 1996; KENDRICK, 1998; LOMAS et al., 1998; HEFFNER, 1998).

Farm animal cognition is currently attracting interest in the context of environmental enrichment (BROOM, 1993; BUCHHOLTZ, 1994). We assume that the suffering which results e.g. from under-demanding, boring environments could be reduced by using innovative technical equipment. However, automated learning devices for larger animals have not as yet been described, although the demand may be especially high when farm animals, which usually live in herds, are to be trained. At time these animals increasingly have to adapt themselves to the technologically equipped environments in which they are kept. So it seems necessary to gain more knowledge of their cognitive abilities under farming conditions.

One aim of our study, therefore, was to develop an effective and suitable method of testing larger group housed animals for their learning capacities and cognitive abilities. Group housing with free access to the training device is not only appropriate from the view of possible practical applications but also makes sure that the animal is motivated and alert while learning. Further, influences of human supervisors are largely prevented.

Another target of the paper is to present first results of our continuing study on visual discrimination learning in goats which were gained in a device that makes possible operant learning in social groups without impeding the scientific evaluation of individual learning data.

\section{Animals and Methods}

Animals

African dwarf goats (Capra hircus L.) from our own Institute's breed were used for the experiments. The founder population was created during a period from 1993 to 1998 by the systematic crossing of parents from seven German zoos. 
The learning experiments described here covered 162 kids, thereof 88 male and 74 female. Two of these animals were excluded from the experiments because they had developed a strategy of drinking water, left by of the others and thus increasingly avoided making choices.

The kids were born in spring and autumn of the years 1998 and 1999. Their average birth weight amounted to $2.08 \mathrm{~kg}$ and $1.95 \mathrm{~kg}$, for the males and females, respectively. All animals were weighed every fourteen days. They reached on an average $18 \mathrm{~kg}$ (males) and $16 \mathrm{~kg}$ (females) at an age of 180 days and were on an average $6 \mathrm{~kg}$ heavier than described in the literature (PETZOLD, 1980; JACOB, 1995). All animals were in a good health condition throughout the experiments and grew well. In the first four weeks the kids were suckled by their mothers, in the following four weeks they were fed with milk or water by an electronic feeder. In addition they had an ad libitum access to hay, water and grain pellets. At the electronic feeder they learned to press the same switch that was later used in the training setup. The boxes provided over $1 \mathrm{~m}^{2}$ per kid.

The average age of the kids when the first learning test started was 130 days. The animals were trained in 16 single-sex groups. The groups consisted of 6 to 17 animals each.

The learning tests were performed in four learning setups so that all the kids of one season could be trained simultaneously.

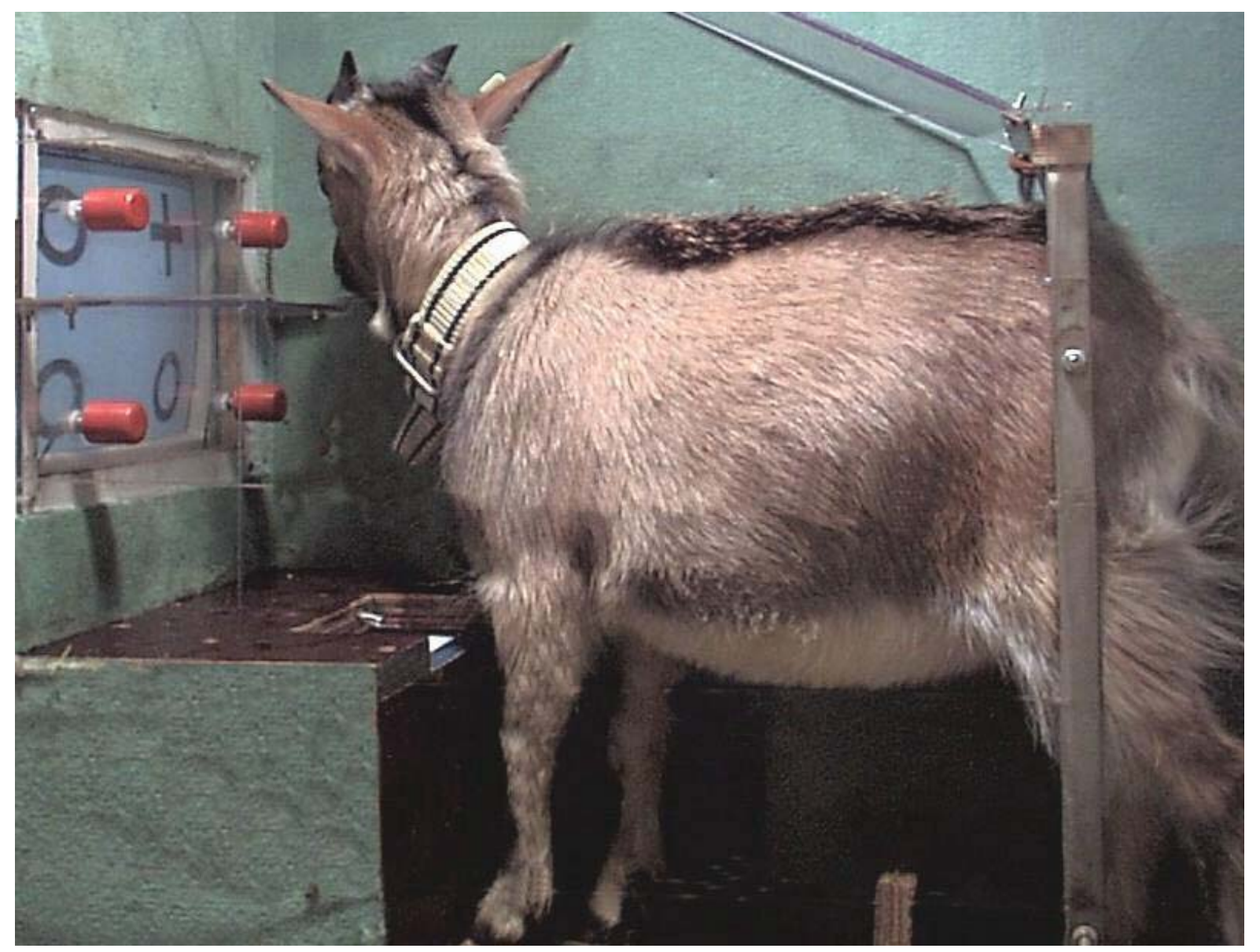

Fig. 1: Goat on the 'Field Monitor' 
The learning device

The animals' learning behavior was examined by four Fields-Monitors. These are general purpose computer systems for behavioral conditioning experiments (FRANZ et al., 1999). Each learning device consists of a 14" computer monitor with the screen covered by clear acrylic glass divided into four sectors where four visual stimuli are presented. Each sector contains a switch (Fig. 1).

If an animal chose the switch with the conditioned visual stimulus the learning device delivered a portion of water $(20-30 \mathrm{ml})$ into a bowl which was fixed about $35 \mathrm{~cm}$ in front of the screen. In this way the animals were forced to retreat after a correct choice, drink the water, and then move back to the screen. This ensured a varying distance from the screen and thus was thought to allow for an individual optimal viewing distance. The height of the upper row of switches above the compartment floor was on the same level with the higherof the eyes in a normal head position.

The animals of a test group had free access to the device at any hour. In order to prevent the animals from disturbing each other while visiting the device and to make sure that they could be registered individually by a responder system (URBAN, Germany), each Fields-Monitor was arranged in a compartment box whose measurements (Fig. 2) made the entry of more than one animal virtually impossible.

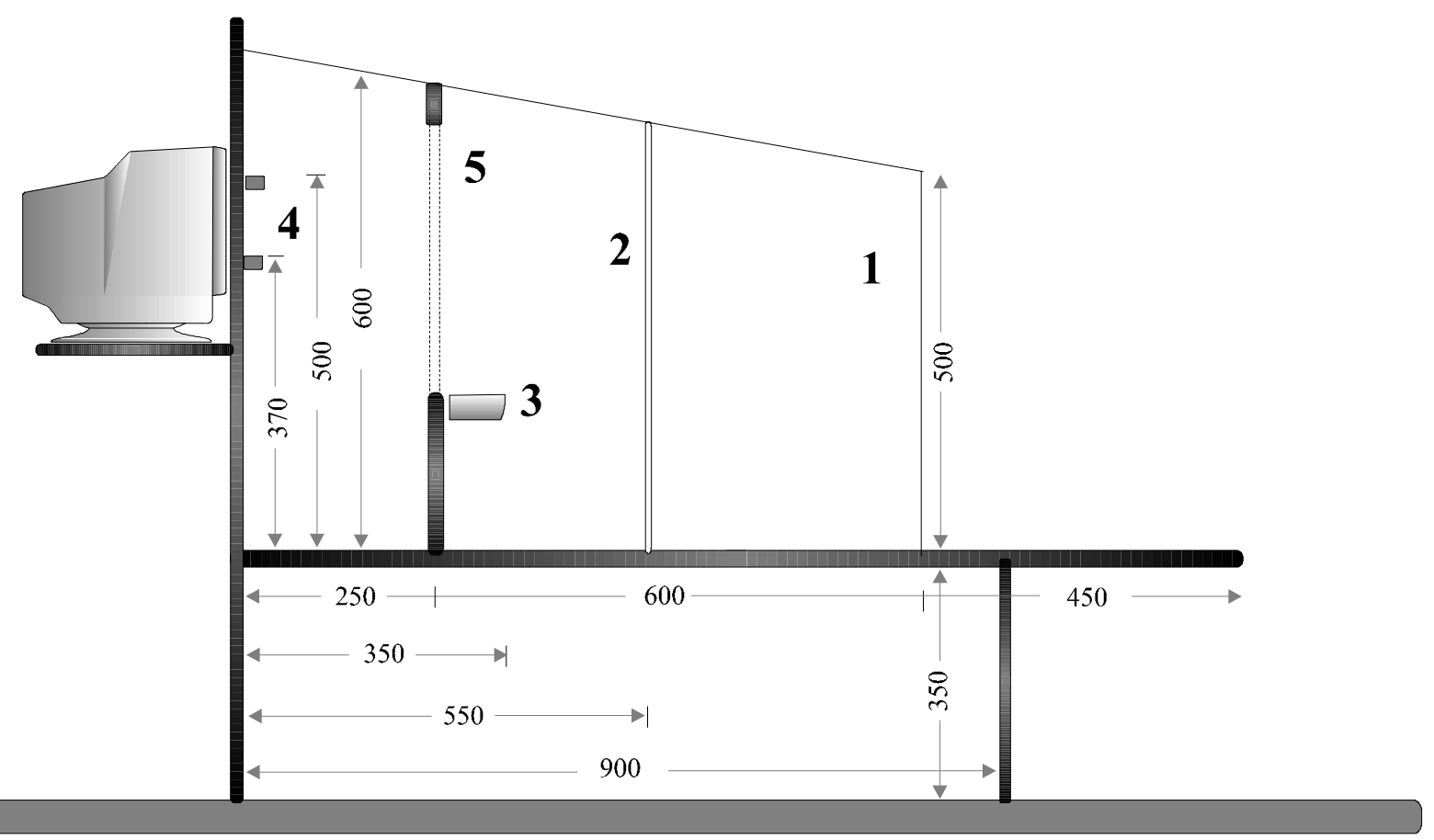

Fig. 2: Measurements of the single box in front of the 'Field Monitor'

(1- wall, 2- aerial for animal identification, 3- bowl, 4- switches, 5- narrow culvert )

The single box had a wooden covering to prevent other animals from jumping in from above. One of the side walls was made of acrylic glass in order to enable the animals to have visual contact with the group. Moreover, this made it possible for the experimenters to watch an animal during its performance and, in addition, provided sufficient illumination of the compartment's interior. The other side wall of the box was made of covered wood and could be shifted sideways so that the size of the single box was adjustable as the animals grew. The single box was placed so that the animals from the group could not see through the transparent side wall. 


\section{Learning procedure}

The animals were subjected to an operant conditioning paradigm for visual pattern discrimination. The patterns used in the different tests are displayed in Table 1.

Table 1

Random probability for correct choice $\left(\mathrm{p}_{0}\right)$ and visual stimuli used in the Learning Tests 1 - 3

\begin{tabular}{llll}
\hline Test Nr. & Po & S+ & S- \\
1 & 0,25 & + & O,O,O \\
2 & 0,25 & $:$ & $-\square \nabla$ \\
3 & 0,25 & S & H, A, N \\
\hline
\end{tabular}

The whole programme included two processes of re-learning a new visual stimulus, though with a constant basic paradigm. In each test one S+ stimulus had to be discriminated from $3 \mathrm{~S}$ - stimuli. The animals were rewarded for each choice of S+ by a portion of water. Our direct observations and careful daily analysis of experimental protocols showed that each animal gained its daily requirement of water by visiting the device as frequently as necessary, depending on its successful individual choices.

Every conditioning test described here took 14 days. The subsequent test was automatically initiated at midnight $(24: 00 \mathrm{~h})$ of the $14^{\text {th }}$ day.

After each actuation of a switch the screen was erased (blacked out). Further actuations within this period were registered but did not result in a reinforcement. The duration of the black-monitor break amounted to 3 seconds in the case of a false choice and some 6-8 seconds after a correct choice, for in the latter case the time required to deliver the reinforcement was also included.

Each actuation of a switch resulted in an acoustic signal which was a pure tone in the case of a correct choice and a mixture of three different tones when an incorrect choice was made.

The positions of the stimuli changed pseudo-randomly after each choice. This periodically repeated pseudo-random series included 32 consecutive offers of 20 different positions of the four stimuli. In order to avoid a non-intended choice of a position instead of the choice of a particular stimulus the same position of the S+ stimulus in more than two successive offers was prevented (FRANZ, 2001).

During conditioning, monitoring took place to establish whether all sectors (positions) were distributed equally among each animal's choices as the random program demands. If this was not the case, i.e. if an animal developed preferences for a certain sector (the left, right, upper or lower one), this was counterbalanced by one of four software subroutines as described below.

The four sectors of the screen are F1 (upper left), F2 (upper right), F3 (lower left) and F4 (lower right), and the numbers of actuations of corresponding sectors made by an individual animal are designated as $\mathrm{f}_{1}, \mathrm{f}_{2}, \mathrm{f}_{3}$ and $\mathrm{f}_{4}$. If in a series of fourteen consecutive actuations of a particular animal $f_{1}+f_{2}$ (upper half) or $f_{3}+f_{4}$ (lower half) or $f_{1}+f_{3}$ (left half) or $f_{2}+f_{4}$ (right half) exceeded 9 , the $\mathrm{S}+$ Stimulus was presented only in the other half of the screen. The two subroutines, working against "horizontal" (left or right) side preferences, had advantage over the two competing subroutines, working against "vertical" (upper or lower) side preferences. As soon as a test animal exhibited $40 \%$ correct choices in a series of 14 actuations, the basic subroutine, 
encompassing all 20 dispositions of stimuli, was re-entered. See FRANZ (2001) for further details of these subroutines.

Each actuation of a switch triggered data collection. The data that were automatically registered were: animal number; time; position of the chosen switch (i.e. screen sector, positions of S+ and S-); current state of the screen (active or black) and, if active, the name of the bitmap containing the currently offered disposition of stimuli; the kind of currently involved subroutine (if any) against side bias. Each new entry to the compartment box by an animal was also recorded, irrespective of whether it made switch actuations or not.

All hard- and software parameters of the presented learning device are flexible. So the kind and amount of reinforcement, the inter-trial interval as well as the number of stimuli which appear on the display in a cyclically repeated series can be modified. Apart from the training regimes with one S+ and three S- stimuli in each offer, testing regimes with four S- (no reinforcement), four S+ (reinforcement by every choice) or two $\mathrm{S}+$ and two $\mathrm{S}$ - regimes are also possible as well as a mixture of different reinforcement regimes within a series of cyclically repeated offers. Corrections against side preference and/or acoustic signals can easily be switched off.

\section{Statistical analysis}

Every conditioning test described here took 14 days.

The daily learning progress of an individual was measured as the rate (LD\%) of correct choices (actuations of $\mathrm{S}+$ ) in relation to all the actuations of switches during a day. As a measure of successful learning over a longer period the LD\% was averaged over the first 10 days of each test and termed ' $10-\mathrm{LD} \%$ '.

The statistical analysis of the data of all 160 goats was carried out according to the following model of analysis of variance with the main factors SEX (male, female) and SEASON (spring, autumn) and a noisy factor 'EXPERIMENTAL GROUP' (16 groups), nested in sex*season. Each analysis was done by 'Test Day' separately.

$$
\begin{aligned}
& \mathrm{y}_{\mathrm{ijkl}}=\mu+\operatorname{sex}_{\mathrm{i}}+\operatorname{seas}_{\mathrm{j}}+\operatorname{sex}^{*} \operatorname{seas}_{\mathrm{ij}}+\operatorname{exgroup}_{\mathrm{k}(\mathrm{ij})}+\mathrm{e}_{\mathrm{ijkl}} \\
& \text { with } \mathrm{y}_{\mathrm{ijk} \mathrm{l}} \quad \text { - } \quad \text { measurement of Goat } \mathrm{l}(\mathrm{l}=1, \ldots, 160) \\
& \mu \quad \text { - overall mean } \\
& \operatorname{sex}_{\mathrm{i}} \quad \text { - } \quad \text { i-th level of factor sex }(\mathrm{i}=1,2) \\
& \text { seas }_{j} \quad \text { - } \quad j \text {-th level of factor season }(j=1,2) \\
& \text { sex }{ }^{*} \text { seas }_{\mathrm{ij}} \quad \text { - } \quad \text { interaction sex*season } \\
& \text { exgroup }_{\mathrm{k}(\mathrm{j})} \quad \text { - } \quad \text { k-th level of factor 'experimental group', nested in } \\
& \text { sex*season } \\
& \mathrm{e}_{\mathrm{ijkl}} \quad-\quad \text { random error }
\end{aligned}
$$

We used procedure GLM of the statistical analysis package SAS ${ }^{\odot}$.

\section{Results}

All animals in a pilot experiment developed a position preference, i.e. a certain area of the screen was preferred to others. Therefore, the learning success could be a mix of position and stimulus choices. 
To resolve the problem, a method was developed for training the animals against position preference as described in the methods section. The results from an experimental comparison with 67 kids are shown in Figure 3.

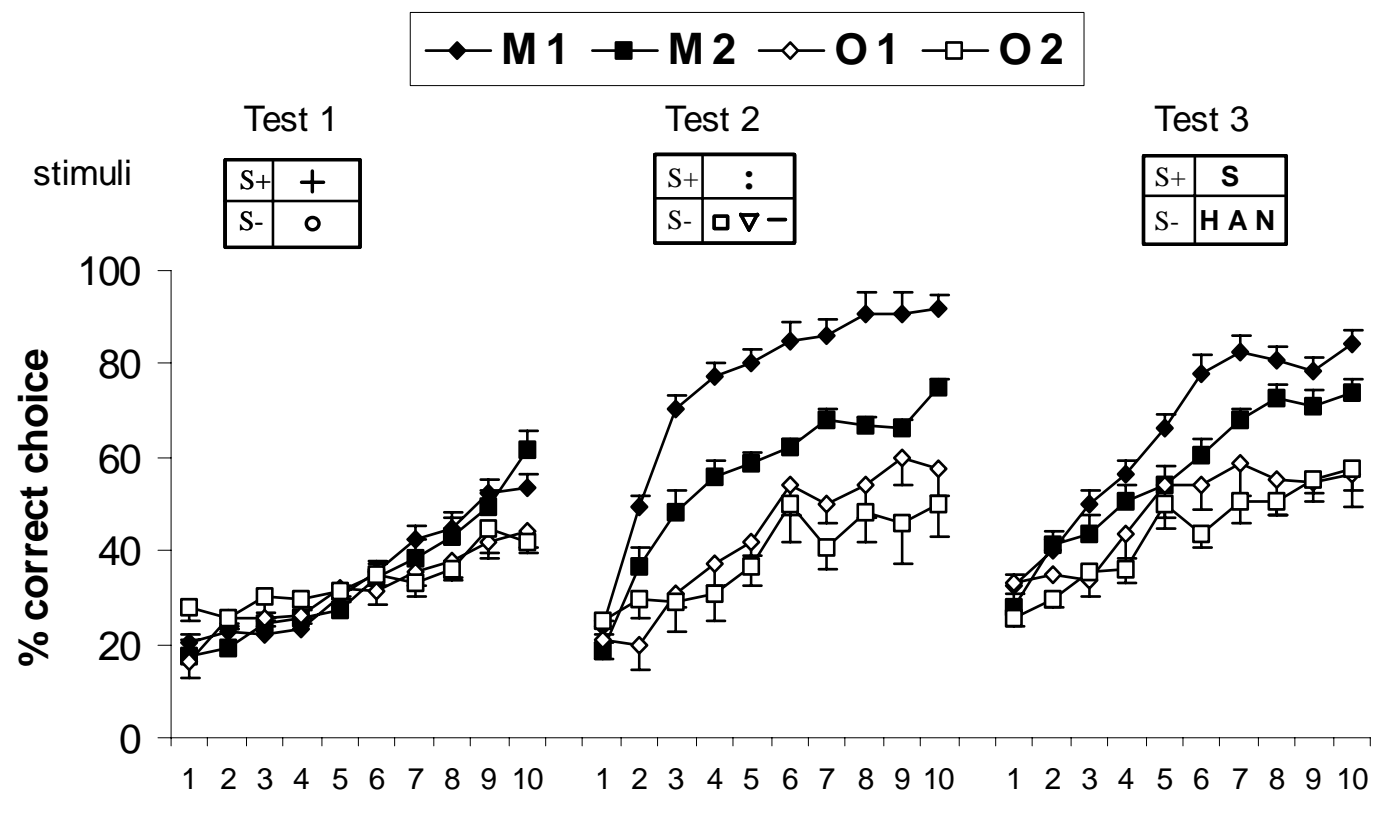

test day

Fig. 3: Mean learning curves of four experimental groups of dwarf goats (LD\%, SE) in 3 visual discrimination tests with (M) and without $(\mathrm{O})$ training against "Position preference" (n=67)

The mean learning curves for the experimental groups which had undergone training against position preference (M1 and M2) were different from the learning curves for experimental groups which had not (O1 and O2). Hence, the results of the 160 animals described in the following were obtained using the described anti-position training procedure.

\section{Group 2}

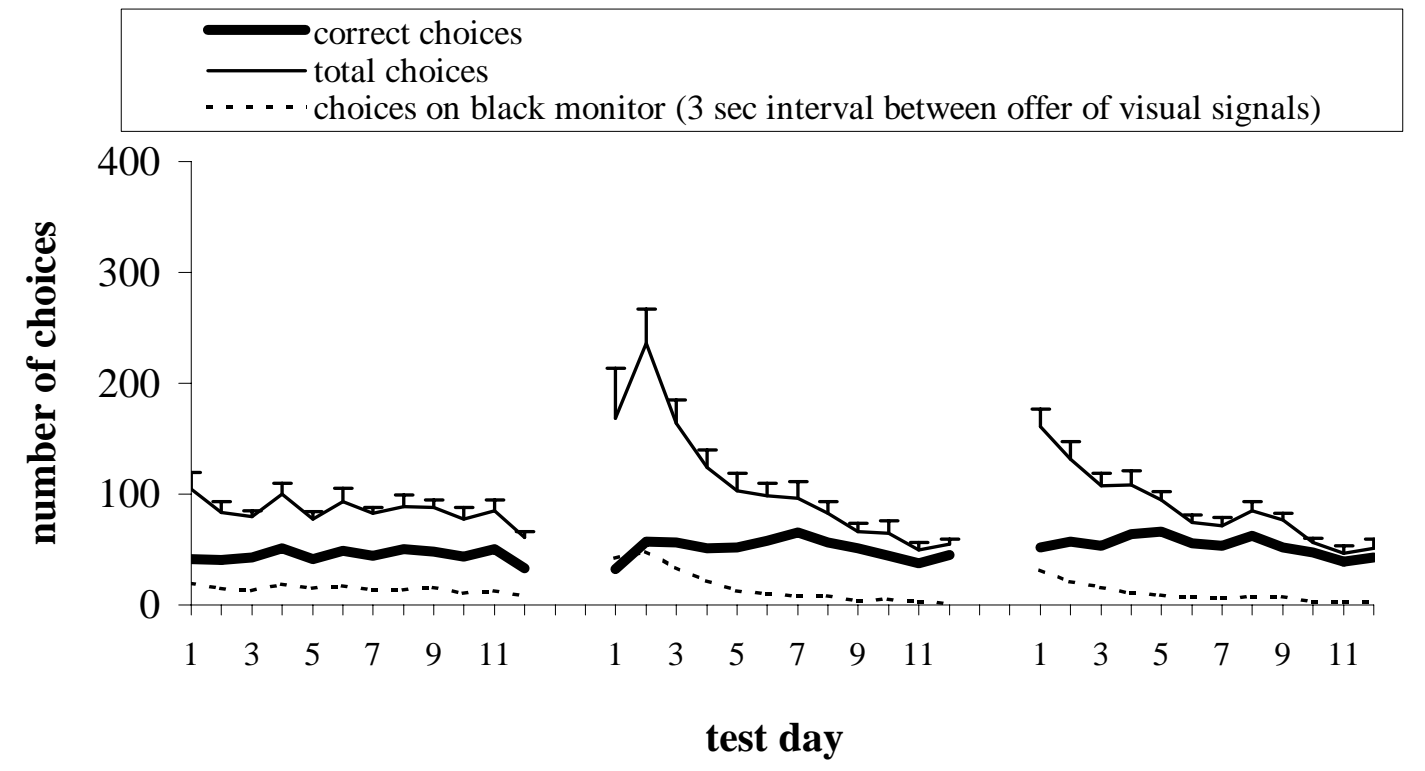

Fig. 4: Number of choices on screen (Mean \pm SE) in Test 1-3 in dependence on test day, when goats are trained with the two-choice paradigm in Test $1(n=13)$. 


\section{Group 4}

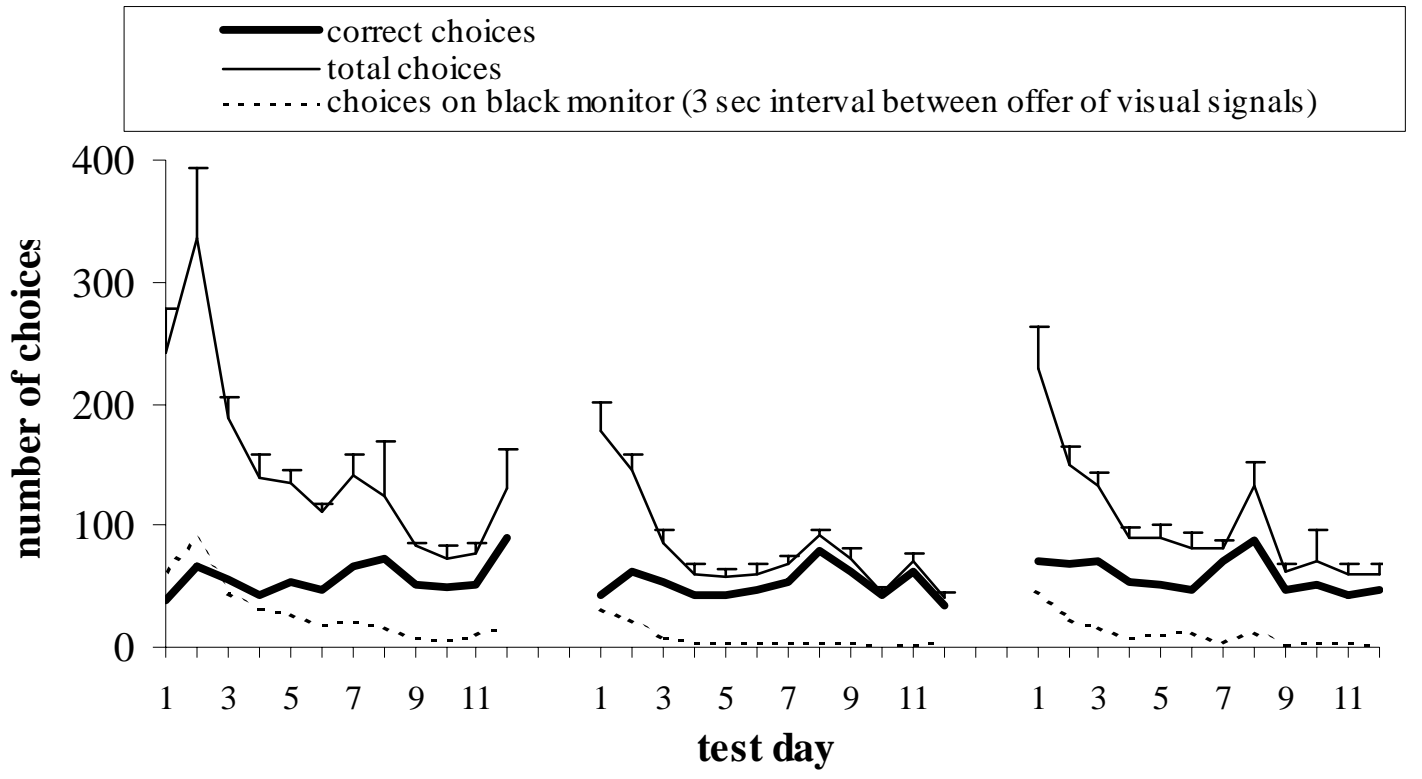

Fig. 5: Number of choices on screen (Mean \pm SE) in Test1-3 in dependence on test day, when goats are trained with the four-choice paradigm in Test $1(n=13)$.

The number of discriminative stimuli presented on the screen of the learning device could exert significant effect on learning progress. To examine this, a pilot experiment was performed with 26 kids. Half of the animals were tested with two stimuli (twochoice paradigm) in Test 1 , the other half with four stimuli (four-choice paradigm). The results are depicted in Figures 4 and 5.

The average number of choices in Test 1 by using the two-choice paradigm was approximately 100 (Fig. 4). The animals of that experimental group achieved no significant learning success in the first 14 days. In the following Test 2 and 3 the average number of choices increased to 250-300 and the animals achieved a learning success in the first four days comparable to that of the other group with a four-choice paradigm in test 1 (Fig. 4 and 5). Therefore the results of the 160 animals described in the following were obtained by using four simultaneous presented stimuli.

The number of choices in the consecutive Learning Tests $1-3$ is shown in Figure 6.

The number of correct choices amounted to approximately 50 per animal and day in all tests and was relatively constant. As the water reward was $25-30 \mathrm{ml}$ per correct choice this resulted in an overall water gain of 1.25-1.5 l per animal and day. With increasing age and weight this value increased slightly, being stabilised in Test 3 at a slightly higher level than in the Tests 1 and 2 (data not shown).

In all tests the average number of actuations on the switches decreased from 160 - 200 on the first day to 80-90 on the tenth day. The number of actuations in the black phase between two pattern presentations also decreased and almost vanished completely in Tests 2 and 3 after seven days (Fig. 6).

The mean learning curves in the three tests are depicted in Figure 7. 

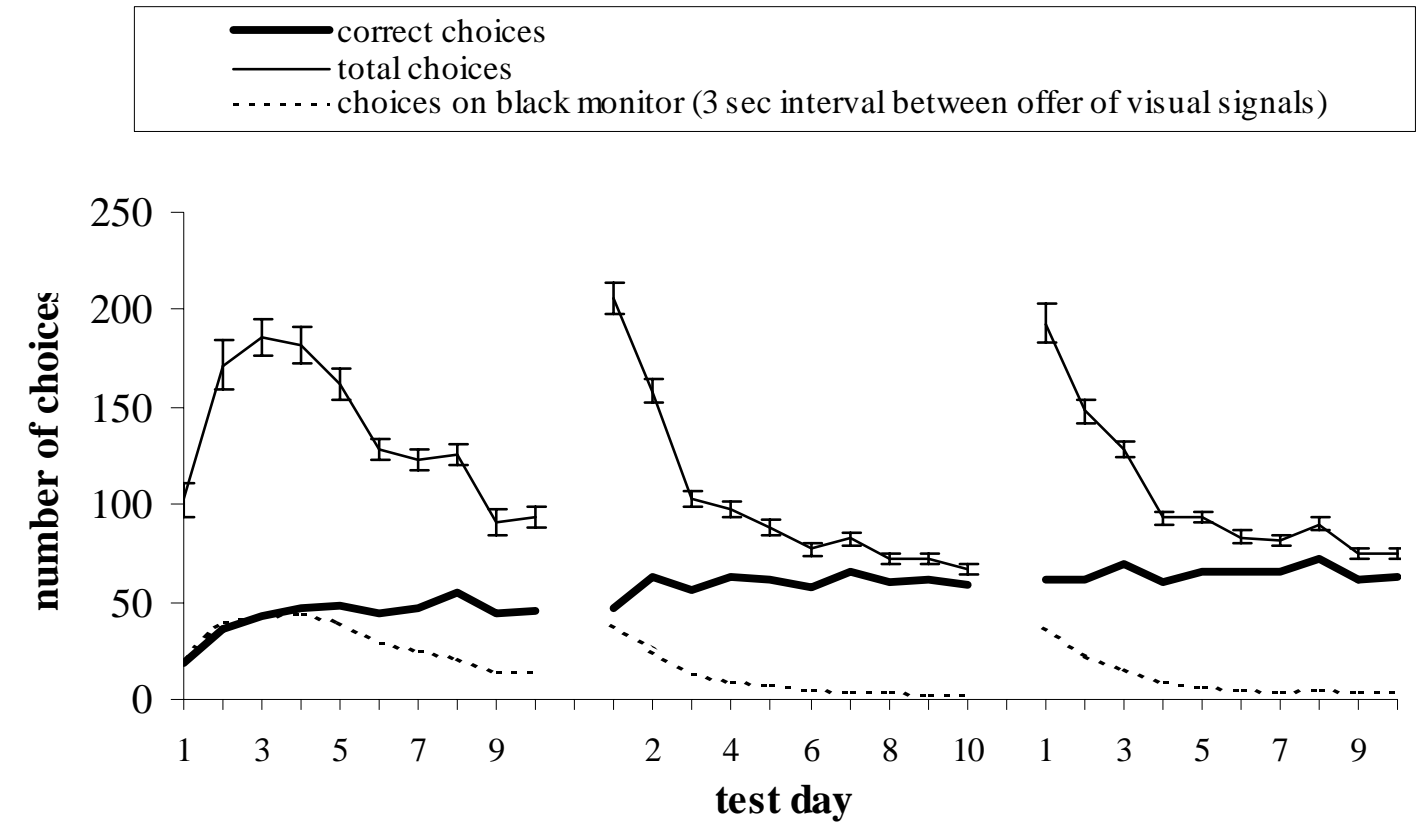

Fig. 6: Number of choices (Mean \pm SE) in dependence on test day in the three consecutive Learning Tests 1-3 for all 160 goats

Test 1

stimuli
Test 2

\begin{tabular}{|c|c|}
\hline S+ & $:$ \\
\hline S- & $\square \nabla-$ \\
\hline
\end{tabular}
Test 3

\begin{tabular}{|l|l|}
\hline S+ & S \\
\hline S- & H A N \\
\hline
\end{tabular}

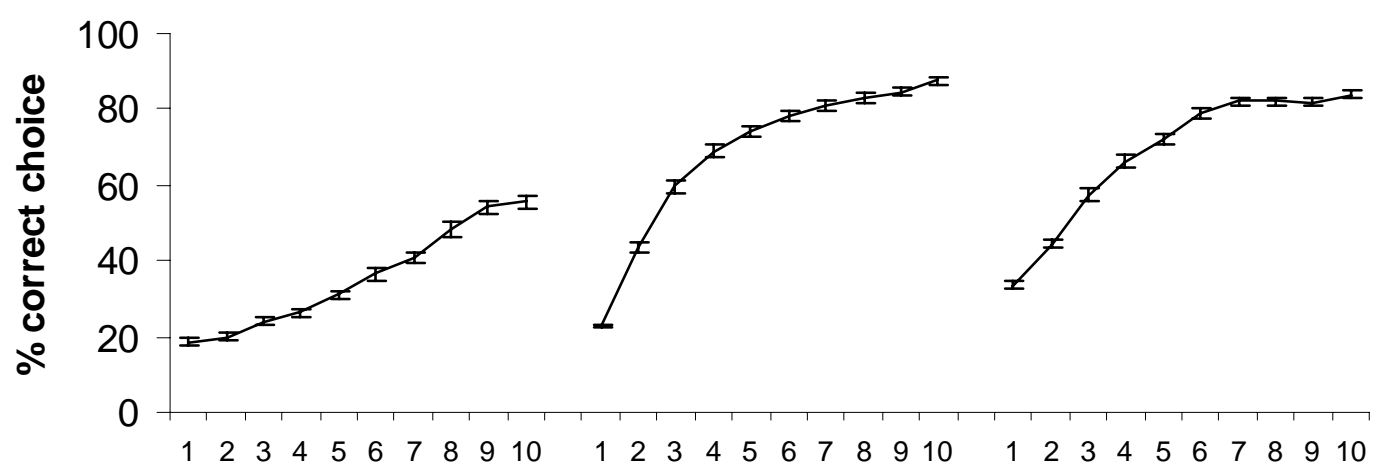

test day

Fig. 7: Mean rate of correct choice $($ Mean \pm SE) of dwarf goats $(n=160)$ in consecutive Learning Tests $1-3$

The increase in learning success was lowest in the naive animals (Test 1). In the consecutive tests there was a considerably higher average increase, where a $70-80 \%$ level was already reached by Day 5 or 6 . The level of correct choices relative to total choices at the first day of Test 3 was founded to be significantly higher in comparison to Test 1 and 2, probably indicating memorization of the adaptive process.

The influence of sex and season on the rate of correct choice in Test 2 is shown in Table 2 where the Least-Square-Means (LSM) and the corresponding standard errors (SE) of 'rate of correct choice' are reported. 
Table 2

Least square-means and standard error for the character 'rate of correct choice' in Test 2 for sex and season estimated by model (1), $n=160$

\begin{tabular}{|c|c|c|c|c|c|c|c|c|c|c|}
\hline & factor & & & & & & & & & \\
\hline \multirow{2}{*}{ Test day } & \multirow[t]{2}{*}{ sex } & \multirow[b]{2}{*}{ LSM } & \multirow[b]{2}{*}{ SE } & \multicolumn{2}{|l|}{ season } & \multirow[b]{2}{*}{ SE } & \multicolumn{2}{|c|}{ sex*season } & \multirow[b]{2}{*}{ LSM } & \multirow[b]{2}{*}{ SE } \\
\hline & & & & & LSM & & & & & \\
\hline 1 & $\begin{array}{l}\text { male } \\
\text { female }\end{array}$ & $\begin{array}{l}22.5 \\
23.5\end{array}$ & $\begin{array}{l}0.77 \\
0.82\end{array}$ & $\begin{array}{l}\text { spring } \\
\text { autumn }\end{array}$ & $\begin{array}{l}22.0 \\
24.0\end{array}$ & $\begin{array}{l}0.8 \\
0.78\end{array}$ & $\begin{array}{l}\text { male } \\
\text { female }\end{array}$ & $\begin{array}{l}\text { spring } \\
\text { autumn } \\
\text { spring } \\
\text { autumn }\end{array}$ & $\begin{array}{l}22.2 \\
22.8 \\
21.8 \\
25.2 *\end{array}$ & $\begin{array}{l}1.1 \\
1.0 \\
1.2 \\
1.1\end{array}$ \\
\hline 2 & $\begin{array}{l}\text { male } \\
\text { female }\end{array}$ & $\begin{array}{l}47.8 \\
38.8\end{array}$ & $\begin{array}{l}1.7 \\
1.8\end{array}$ & $\begin{array}{l}\text { spring } \\
\text { autumn }\end{array}$ & $\begin{array}{l}37.4 \\
49.1\end{array}$ & $\begin{array}{l}1.8 \\
1.8\end{array}$ & $\begin{array}{l}\text { male } \\
\text { female }\end{array}$ & $\begin{array}{l}\text { spring } \\
\text { autumn } \\
\text { spring } \\
\text { autumn }\end{array}$ & $\begin{array}{l}43.3 \\
52.3 \\
31.6 \\
45.9 *\end{array}$ & $\begin{array}{l}2.5 \\
2.4 \\
2.7 \\
2.5\end{array}$ \\
\hline 3 & $\begin{array}{l}\text { male } \\
\text { female }\end{array}$ & $\begin{array}{l}65.0 \\
53.6\end{array}$ & $\begin{array}{l}1.9 \\
2.0\end{array}$ & $\begin{array}{l}\text { spring } \\
\text { autumn }\end{array}$ & $\begin{array}{l}53.4 \\
65.1 *\end{array}$ & $\begin{array}{l}2.0 \\
1.9\end{array}$ & $\begin{array}{l}\text { male } \\
\text { female }\end{array}$ & $\begin{array}{l}\text { spring } \\
\text { autumn } \\
\text { spring } \\
\text { autumn }\end{array}$ & $\begin{array}{l}60.5 \\
69.4 * \\
46.3 \\
60.9 *\end{array}$ & $\begin{array}{l}2.8 \\
2.7 \\
3.0 \\
2.8\end{array}$ \\
\hline 4 & $\begin{array}{l}\text { male } \\
\text { female }\end{array}$ & $\begin{array}{l}73.8 \\
63.0 *\end{array}$ & $\begin{array}{l}1.9 \\
2.0\end{array}$ & $\begin{array}{l}\text { spring } \\
\text { autumn }\end{array}$ & $\begin{array}{l}63.4 \\
73.4\end{array}$ & $\begin{array}{l}2.0 \\
1.9\end{array}$ & $\begin{array}{l}\text { male } \\
\text { female }\end{array}$ & $\begin{array}{l}\text { spring } \\
\text { autumn } \\
\text { spring } \\
\text { autumn } \\
\end{array}$ & $\begin{array}{l}71.5 \\
76.2 \\
55.3 \\
70.7 *\end{array}$ & $\begin{array}{l}2.7 \\
2.6 \\
2.9 \\
2.8\end{array}$ \\
\hline 5 & $\begin{array}{l}\text { male } \\
\text { female }\end{array}$ & $\begin{array}{l}76.9 \\
70.5 *\end{array}$ & $\begin{array}{l}1.9 \\
2.0\end{array}$ & $\begin{array}{l}\text { spring } \\
\text { autumn }\end{array}$ & $\begin{array}{l}67.9 \\
79.5 *\end{array}$ & $\begin{array}{l}2.0 \\
1.9\end{array}$ & $\begin{array}{l}\text { male } \\
\text { female }\end{array}$ & $\begin{array}{l}\text { spring } \\
\text { autumn } \\
\text { spring } \\
\text { autumn }\end{array}$ & $\begin{array}{l}74.3 \\
79.5 \\
61.4 \\
79.5 *\end{array}$ & $\begin{array}{l}2.7 \\
2.7 \\
2.9 \\
2.8\end{array}$ \\
\hline 6 & $\begin{array}{l}\text { male } \\
\text { female }\end{array}$ & $\begin{array}{l}80.1 \\
75.7\end{array}$ & $\begin{array}{l}1.9 \\
2.0\end{array}$ & $\begin{array}{l}\text { spring } \\
\text { autumn }\end{array}$ & $\begin{array}{l}74.8 \\
80.9 *\end{array}$ & $\begin{array}{l}1.9 \\
1.9\end{array}$ & $\begin{array}{l}\text { male } \\
\text { female }\end{array}$ & $\begin{array}{l}\text { spring } \\
\text { autumn } \\
\text { spring } \\
\text { autumn }\end{array}$ & $\begin{array}{l}80.0 \\
80.2 \\
69.7 \\
81.6 *\end{array}$ & $\begin{array}{l}2.6 \\
2.6 \\
2.8 \\
2.7\end{array}$ \\
\hline 7 & $\begin{array}{l}\text { male } \\
\text { female }\end{array}$ & $\begin{array}{l}83.6 \\
78.0 *\end{array}$ & $\begin{array}{l}1.6 \\
1.8\end{array}$ & $\begin{array}{l}\text { spring } \\
\text { autumn }\end{array}$ & $\begin{array}{l}77.6 \\
84.0 *\end{array}$ & $\begin{array}{l}1.7 \\
1.7\end{array}$ & $\begin{array}{l}\text { male } \\
\text { female }\end{array}$ & $\begin{array}{l}\text { spring } \\
\text { autumn } \\
\text { spring } \\
\text { autumn }\end{array}$ & $\begin{array}{l}83.7 \\
83.6 \\
71.6 \\
84.3 *\end{array}$ & $\begin{array}{l}2.3 \\
2.3 \\
2.6 \\
2.4\end{array}$ \\
\hline 8 & $\begin{array}{l}\text { male } \\
\text { female }\end{array}$ & $\begin{array}{l}85.0 \\
80.4\end{array}$ & $\begin{array}{l}1.9 \\
2.0\end{array}$ & $\begin{array}{l}\text { spring } \\
\text { autumn }\end{array}$ & $\begin{array}{l}81.4 \\
84.0\end{array}$ & $\begin{array}{l}2.0 \\
1.9\end{array}$ & $\begin{array}{l}\text { male } \\
\text { female }\end{array}$ & $\begin{array}{l}\text { spring } \\
\text { autumn } \\
\text { spring } \\
\text { autumn }\end{array}$ & $\begin{array}{l}85.9 \\
84.1 \\
76.9 \\
83.9\end{array}$ & $\begin{array}{l}2.6 \\
2.7 \\
3.0 \\
2.7\end{array}$ \\
\hline 9 & $\begin{array}{l}\text { male } \\
\text { female }\end{array}$ & $\begin{array}{l}87.0 \\
82.2 *\end{array}$ & $\begin{array}{l}1.3 \\
1.5\end{array}$ & $\begin{array}{l}\text { spring } \\
\text { autumn }\end{array}$ & $\begin{array}{l}83.5 \\
85.7\end{array}$ & $\begin{array}{l}1.4 \\
1.4\end{array}$ & $\begin{array}{l}\text { male } \\
\text { female }\end{array}$ & $\begin{array}{l}\text { spring } \\
\text { autumn } \\
\text { spring } \\
\text { autumn }\end{array}$ & $\begin{array}{l}87.4 \\
86.6 \\
79.5 \\
84.8\end{array}$ & $\begin{array}{l}1.8 \\
1.9 \\
2.1 \\
2.0\end{array}$ \\
\hline 10 & $\begin{array}{l}\text { male } \\
\text { female }\end{array}$ & $\begin{array}{l}88.7 \\
86.1\end{array}$ & $\begin{array}{l}1.3 \\
1.4\end{array}$ & $\begin{array}{l}\text { spring } \\
\text { autumn }\end{array}$ & $\begin{array}{l}86.9 \\
88.0\end{array}$ & $\begin{array}{l}1.4 \\
1.3\end{array}$ & $\begin{array}{l}\text { male } \\
\text { female }\end{array}$ & $\begin{array}{l}\text { spring } \\
\text { autumn } \\
\text { spring } \\
\text { autumn }\end{array}$ & $\begin{array}{l}89.7 \\
87.7 \\
84.0 \\
88.2\end{array}$ & $\begin{array}{l}2.0 \\
1.9 \\
2.0 \\
1.9\end{array}$ \\
\hline
\end{tabular}

* denotes significant differences - significance level $\mathrm{p}=0.05$

Due to the corresponding F-tests of the analysis of variance we found a significant influence of sex from Test Day 2 to 9 (males had a higher rate of correct choice than females), a significant influence of season from Test Day 2 to 7 (the autumn cohorts learned better than the spring cohorts) and a significant influence of the noisy factor 'Experimental Group' from Test day 1 to 6 and at Test Day 9.

If we examined the interaction sex*season by a statistical approach in more detail we found that the differences between seasons are only significant from Test Day 4 to 7 for female goats. After Test Day 7 we found no influence of season and sex. 
Furthermore, if we consider autumn only, we found no significant differences for sex from Test Day 4 to 10.

\section{Discussion}

Keeping animals in social groups while they are trained in operant learning paradigms offers several advantages over the training of single animals, since a larger number has to reach a demanded skill in a short time. If the device is well designed the animals can decide by themselves when they train. This will usually be in the time when they are most highly motivated. Further, the use of one learning device for a group of animals is cheaper than keeping a single experimental animal in a housing with its own learning device, not to mention the avoidance of social deprivation. In addition, the effect of the influence of the experimenter is largely excluded (MEIER et al., 1997). Thus the developed general purpose computer system for behavioral conditioning experiments with group-housed larger animals eliminates most of the stress factors known to decrease learning success (NICOL, 1996; MENDL, 1999 and references therein).

Visual discrimination learning has been demonstrated in a variety of birds and mammals, including some farm animals (cf. DOUGHERTY et al., 1991; KENDRICK et al., 1995). So, it was less the question of whether or not goats are able to learn to perform such a task than of examining the conditions that ease learning. This should be achieved under typical environmental conditions, such as living in a herd.

Visual learning in goats was examined by SOLTYSIK and BALDWIN (1972), BALDWIN (1979), FEHRINGER (1979), and BUCHENAUER and FRITSCH (1980). All these authors showed that goats are well able to solve visual discrimination tasks. BALDWIN (1979) tested four goats. One of these reached a score of $60 \%$ correct responses after four sessions with 50 single reinforcements each. In the experiments carried out by FEHRINGER (1979) the same stimuli were used as by BALDWIN (1979), and in our Test 1: a circle and a cross. FEHRINGER (1979) reported successful learning after 18 days of training with 393 sessions. In a study by FRANZ and GAJDON (1999), and FRANZ and ROITBERG (2001), similar results were achieved with a group of 13 goats when the animals had to choose from two stimuli, one S+ and one S-. However, when 4 stimuli were used, one S+ and three times the same S-, as in Test 1 of this study, another group of 13 goats achieved a significant learning score after only four days. It could be shown that this was not an effect of the group since in a subsequent test with four stimuli the first group also performed well.

The effect of a better learning with one $S+$ against three equal $S$ - stimuli instead of one $\mathrm{S}+$ versus one $\mathrm{S}$ - may be a result of the higher salience that the $\mathrm{S}+$ stimulus gains in a simultaneous presentation. In addition, having to choose one pattern out of four reduces hitting the correct switch by chance to a half. This may pose a stronger pressure on the animals, directing their attention more forcibly to the visual stimuli. It is for these reasons that we chose this paradigm in the present study.

The three tests of this study revealed that about 3-4 days of training are sufficient to achieve an association of the visual patterns with a water reinforcement. This was, in all three tests, indicated not only by increasing learning curves but also by a decreasing number of actions during the blank screen phase. This shows that the animals have learned to recognise the optical patterns as meaningful indicators of reinforcement. 
Consequently, the animals learned conspicuously faster in Tests 2 and 3. This may be attributed to attentional weighting (GOLDSTONE, 1998). After achieving the goal (i.e. by satisfying the goat's thirst) behavioral actions diminish or disappear, explaining the relative invariability of the number of correct decisions observed in the presented data (roughly 50 correct acts correspond to a sufficient daily water ration of about one liter). In turn, our results show a significant impact of seasons, sex of goats and unconditioned behavior (preference of a particular place at the monitor) on conditioning progress. An explanation of these responses revealed by exposing the goats to device-mediated operant conditioning appears to be partly possible in view of the plasticity of neuronal modules as the basis of learning behavior. A previous study on visual operant conditioning in calves (using a reward paradigm like the schedule used in the present investigation) revealed that the associating discriminative stimuli in operant conditioning changed the receptor patterns for major neurotransmitters in the thalamus (LÖHRKE and FRANZ, 1995) and in the visual cortex (LÖHRKE et al., 1995).

In turn, memory formation, an essential process of learning, is known to involve multiple forms and places of memory storage. Current view holds that forms of knowledge (in human declarative and procedural forms) acquired during learning have to be considered rather than the sensory or motor systems involved (MENZEL, 1995). Although it is not yet entirely clear what declarative learning corresponds to in animals, navigational and configural learning in mammals appear to be closely related to human declarative learning and need the functional hippocampus as well neocortical and subcortical areas for acquistion (ALVAREZ and SQUIRE, 1994). Hippocampal synapses have been proved to be easily modifiable in strength, and abundance (ALVAREZ and SQUIRE, 1994; MADANI, 1999), i. e. in properties that are presumed to be necessary for memory function (JEFFERY et al., 1995). The visual stimuli used in operant conditioning by the learning device induce constraints for configural discrimination such as discrimination of letters. Hence, changes in hippocampal neuronal functions may occur as a consequence of this type of conditioning.

Hippocampal CA3 neurons are connected with septal nuclei and the medial and basal forebrain (YOUNG, 1995). Some lateral mammalian hypothalamus neurons also project to these areas (FLIER and MARATOS-FLIER, 1998). Therefore hypothalamus output can modify hippocampal performance. This can occur at neuroendocrine level, since neurons of the hypothalamus and some other brain centers express aromatase, an enzyme that converts androgens such as testosterone to estradiol-17 $\beta$. The steroid regulates sex-specific differentiation of brain functions via nuclear estrogen receptors in mice (EHRET et al., 1993). Male hypothalamic neurons possess a higher capacity for estradiol formation compared to female mice (HINTERSDORF and EHRET, 1996). Given this is true also in goats, sex-specific differences observed in conditioning progress using the learning device could be seen as a consequence of estrogen effect on initial hippocampal output concerning memory formation, since the difference disappeared during the late period of conditioning. However, information neither about aromatase expression nor about hypothalamic-hippocampal axes is yet available in goats to our knowledge. Work is ongoing to close these gaps to understand at physiological level the behavioral responses revealed by the learning device. 


\section{Conclusion}

The Fields-Monitor, a computer monitor simultaneously displaying four visual stimuli with actuator switches mounted close to each pattern has been shown to be suitable equipment to train larger animals. They may live in herds if a training compartment is used that ensures that only one animal works with the device at a time. Such a compartment also allows the individual recognition of an animal and the attribution of its actions. The results gained with this set-up show individual differences in learning success that lie within the range of variation coefficients known for other physiological traits.

Other types of application for this new learning equipment for group housed animals could be opened up in the training of a larger number of laboratory animals for complex tasks in a short time. Further, this presented method will also open up new possibilities for improving the environment of zoo animals.

\section{Acknowledgements}

The authors gratefully acknowledge the expert technical assistance of Katrin Siebert and Dieter Sehland and their untiring care for the animals and the training technique.

Mr. P. Plant is gratefully acknowledged for improving the English style of the manuscript.

This research was supported by the Deutsche Forschungsgemeinschaft (F 1481/1-1).

\section{References}

ALVAREZ, P.; SQUIRE, L.D.:

Memory consolidation and the medial temporal lobe. Proc. Nat. Acad. Sci. USA 91 (1994), 7041-7045 ARAVE, C.W.:

Assessing sensory capacity of animals using operant technology. J. Anim. Sci. 74 (1996), 1996-2009

BALDWIN, B.A.: Operant studies on shape discrimination in goats. Physiol. Behav. 23 (1979), 455-459

BROOM, D.M.:

A usable definition of animal welfare. J. Agric. Envir. Ethics 6 (suppl. 2) (1993), 15-25

BUCHENAUER, D.; FRITSCH, B.:

Zum Farbsehvermögen von Hausziegen (Capra hircus L.). Z. Tierpsychol. 53 (1980), 225-230

BUCHHOLTZ, C.:

Verhaltensstörungen bei Versuchstieren als Ausdruck schlechter Befindlichkeit. Tierärztl. Umschau 49 (1994), 532-538

DOUGHERTY, D.M.; LEWIS, P.:

Stimulus generalization, discrimination learning and peak shift in horses. J. exp. Anal. Behav. 56 (1991), 97-104

EHRET, G.; JÜRGENS, A.; KOCH, M.: Neuroreport 4 (1993), 1247-1250

FEHRINGER, C.H.:

Versuche zum visuellen Lernen bei Afrikanischen Zwergziegen (Capra hircus L.). Justus-LiebigUniversität Gießen, PhD Thesis ,1979

FLIER, J.S.; MARATOS-FLIER, E.:

Obesity and the hypothalamus: noval peptides for new pathways. Cell 92 (1998), 437-440

FRANZ, H.; GAJDON, G.:

Comparison between a simultaneous discrimination task for dwarf goats (Capra hircus L.) with two and four stimuli. Proc. $33^{\mathrm{d}}$ International Congress of the International Society for Applied Ethology, Lillehammer, Norway, 17-21 August 1999, 207

FRANZ,.H.:

Zum Einfluss der Trainingsmethode auf das Lernverhalten von Zwergziegen am Computer. Arch. Tierz., Dummerstorf 44 (2001), 553-560 
FRANZ, H.; ROITBERG, E.:

Ein Vergleich des Lernerfolges von Zwergziegen bei simultaner Zweifach- oder VierfachwahlFRANZ, H.: möglichkeit in visuellen Differenzierungsaufgaben. Arch. Tierz., Dummerstorf 44 (2001), 661-669

Methode zur Untersuchung der Lernfähigkeit von Kälbern in Gruppenhaltung und Ergebnisse bei visuellen Differenzierungsaufgaben. Arch. Tierz., Dummerstorf 42 (1999), 241-254

FRANZ, H.; REICHART, H.:

Der Feldmonitor - eine neue Möglichkeit der Lernforschung mit Tieren und Ergebnisse bei visuellen Differenzierungsaufgaben von Zwergziegen. Arch. Tierz., Dummerstorf 42 (1999), 481-493

GOLDSTONE, R.L.:

Perceptual learning. Ann. Rev. Psychol. 49 (1998), 585-612

HEFFNER, H.E.

Auditory awareness. Appl. Anim. Behav. Sci. 57 (1998), 259-268

HINTERSDORF, U.; EHRET, G.:

Parental motivation in mice correlates with c-fos expression in the limbic system. In: Brain and Evolution. Proc.. 24th Göttingen Neurobiology Conf. Vol I. ed .N. ELSNER \& H.U. SCHNITZLER, Georg Thieme Verlag Stuttgart-New York (1996), 16

JACOB, U.:

Ziegenhaltung bei Kleinbauern in Burundi. Humboldt-Universität Berlin, PhD Thesis, 1995

JEFFERY, K.J.; BANNERMAN, D..M.; MORRIS, R.G..M.:

Attempting to bridge the gap between synaptic plasticity and learning. In: Learning and Memory. Proc. 23rd Göttingen Neurobiol. Conf. Vol. I, ed. N. ELSNER and R MENZEL, Georg Thieme Verlag Stuttgart-New York (1995), 105-128

KENDRICK, K.M.; ATKINS, K.; HINTON, M.R.; BROAD, K.D.; FAVBRE-NYS, C.; KEVERNE, B.: Facial and vocal discrimination in sheep. Anim. Behav. 49 (1995), 1665-1676

KENDRICK, K.M.: Intelligent perception. Appl. Anim. Behav. Sci. 57 (1998), 213-231

KILGOUR, R.; FOSTER, T..M.; TEMPLE, W.; MATTHEWS, L.R.; BREMNER, K.J.:

Operant technology applied to solving farm animal problems. An assessment. Appl. Anim. Behav. Sci. 30 (1991), 141-166

LOMAS, C.A.; PIGGINGS, D.; PHILIPS, C.J.C.:

Visual awareness. Appl. Anim. Behav. Sci. 57 (1998), 247-257

LÖHRKE, B.; FRANZ, H.:

Effects of operant conditioning on receptor pattern in membranous thalamic cell fragments In: Learning and Memory. Proceed. 23rd Göttingen Neurobiology Fonc. Vol. I, ed. N. ELSNER \& R. MENZEL, Georg Thieme Verlag Stuttgart-New York (1995), 78

LÖHRKE, B.; FRANZ, H.; BROSE, R.; KLEIN, M.:

Alterations in the visual cortex receptor pattern by operant conditioning in a reward paradigm. Biol. Chem. 376 (1995), 483-493

MADANI, R.:

Enhanced hippocampal long-term potentiation and learning by increased neuronal expression of tissuetype plasminogen activator in transgenic mice. EMBO J. 18 (1999), 3007-3012

MEIER, M.; REINERMANN, R.; WARLICH, J.; MANTEUFFEL, G.:

An automated training device for pattern discrimination learning of group-housed gerbils. Physiol. Behav. 63 (1997), 397-498

MENDL, M.:

Performing under pressure: stress and cognitive function. Appl. Anim. Behav. Sci. 65 (1999), 221-244

MENZEL, R.:

Learning and Memory. In: Learning and Memory. Proceed 23rd Göttingen Neurobiology Conf. Vol. I, ed. N. ELSNER \& R MENZEL Georg Thieme Verlag Stuttgart-New York (1995), 5-10

NICOL, C.J.:

Farm animal cognition. Anim. Sci. 62 (1996), 375-391

PETZOLD, G.:

Metrische Untersuchungen zur Jugendentwicklung afrikanischer Zwergziegen in Zoologischen Gärten. Milu, Berlin 5 (1980), 5-20

SOLTYSIK, S.; BALDWIN, B.A.:

The performance of goats in triple choice delayed response tasks. Acta Neurobiol. Exp. 32 (1972), 7386 
YOUNG, J.Z.:

Emerging ideas on memory in multiple matrices and with cyclic re-excitation. In: Learning and Memory. Proceed. 23rd Göttingen Neurobiology Conf. Vol. I, ed. N. ELSNER, R. MENZEL, Georg Thieme Verlag Stuttgart-New York (1995), 61-82

Received: 2002-03-15

Accepted: 2002-07-02

Authors' addresses

Dr. HARTMUT FRANZ*, Dr. EVGENI ROITBERG, Dr. BERTHOLD LÖHRKE, Dr. GERD NÜRNBERG, Dr. GERHARD DIETL**

Forschungsinstitut für die Biologie landwirtschaftlicher Nutztiere

Wilhelm-Stahl-Allee 2

D-18196 Dummerstorf

Germany

Prof. Dr. RAGNAR KINZELBACH

Institut für Biodiversitätsforschung / Allgemeine \& Spezielle Zoologie

Universität Rostock

Universitätsplatz 2

D-18055 Rostock

Germany

*present address

Parkweg 11

D-18196 Dummerstorf

Germany

E-Mail: Dr.H.Franz@gmx.net

**Corresponding author

E-Mail: dietl@fbn-dummerstorf.de 